University of Nebraska - Lincoln

DigitalCommons@University of Nebraska - Lincoln

2015

Affinity Chromatography: A Historical Perspective

David S. Hage

Ryan E. Matsuda

Follow this and additional works at: https://digitalcommons.unl.edu/chemistryhage

Part of the Medicinal-Pharmaceutical Chemistry Commons

This Article is brought to you for free and open access by the Published Research - Department of Chemistry at DigitalCommons@University of Nebraska - Lincoln. It has been accepted for inclusion in David Hage Publications by an authorized administrator of DigitalCommons@University of Nebraska - Lincoln. 


\title{
Affinity Chromatography: A Historical Perspective
}

\author{
David S. Hage and Ryan Matsuda
}

University of Nebraska-Lincoln

\begin{abstract}
Affinity chromatography is one of the most selective and versatile forms of liquid chromatography for the separation or analysis of chemicals in complex mixtures. This method makes use of a biologically related agent as the stationary phase, which provides an affinity column with the ability to bind selectively and reversibly to a given target in a sample. This review examines the early work in this method and various developments that have lead to the current status of this technique. The general principles of affinity chromatography are briefly described as part of this discussion. Past and recent efforts in the generation of new binding agents, supports, and immobilization methods for this method are considered. Various applications of affinity chromatography are also summarized, as well as the influence this field has played in the creation of other affinity-based separation or analysis methods.

Keywords: Affinity chromatography, History, High-performance affinity chromatography, Bioaffinity chromatography, Immunoaffinity chromatography, Immobilized metal-ion affinity chromatography, Dye-ligand affinity chromatography, Biomimetic affinity chromatography, Affinity monolith Chromatography
\end{abstract}

Published as Chapter 1 in Senta Reichelt (ed.), Affinity Chromatography: Methods and Protocols, Methods in Molecular Biology, vol. 1286, pp 1-19.

DOI: $10.1007 / 978-1-4939-2447-9 \_1$

Copyright (C) 2015 Springer Science+Business Media New York. Used by permission 


\section{Introduction}

Most samples in nature consist of a complex mixture of many substances. This fact has led to the development of chemical separation methods such as liquid chromatography to purify, analyze, or examine the components of such samples. The variety of chemical interactions and formats that can be employed in these separations, as based on the types of stationary phases and mobile phases that are used, has resulted in the creation of many types of liquid chromatography [1]. For instance, reversed phase chromatography or normal phase chromatography can be utilized to separate chemicals based on their polarity, ion exchange chromatography makes use of ionic interactions, and size exclusion chromatography separates chemicals based on their size. Such methods can also be classified as low-performance or high-performance techniques based on the support materials that are used and the types of column efficiencies that are obtained. The large variety of such methods has resulted in liquid chromatographic methods being employed for the separation or analysis of many types of chemicals in liquid-phase samples. As a result, it is not surprising that liquid chromatography is a common liquid-phase separation method that is found in both industrial settings and research laboratories [1].

Perhaps the most selective, versatile, and complex form of liquid chromatography is the method of affinity chromatography. This method is a type of liquid chromatography that uses a biologically related agent as the stationary phase [2-7]. As this definition suggests, affinity chromatography is based on the reversible and specific binding that is often found in biological interactions. Examples of these interactions include the binding of an antibody with its target (or antigen), the binding of a hormone with its receptor, and the interaction of an enzyme with its substrate. This type of selective binding is used in affinity chromatography by placing within the column one of the interacting agents and immobilizing this agent to a support for use as a stationary phase. This immobilized binding agent is called the "affinity ligand," and it forms the basis by which the complementary target can be isolated or purified by the affinity column. 
a Apply Sample to Affinity Column

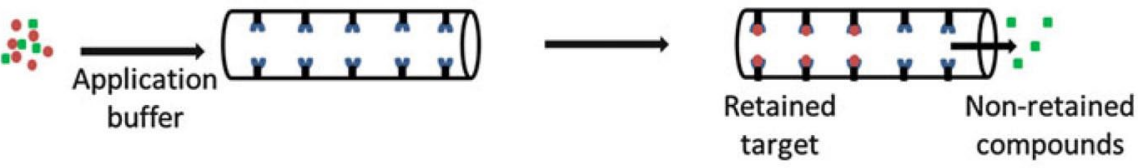

b Elute Retained Target(s)

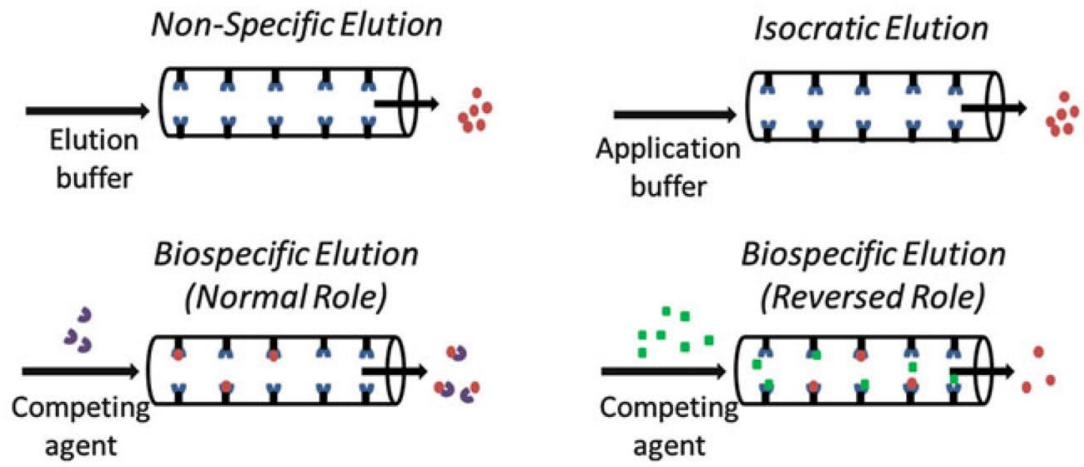

Fig. 1 Examples of typical (a) application and (b) elution sequences for affinity chromatography. The isocratic elution method in (b) uses the same solution for both sample application and elution from the column. The nonspecific elution method in (b) uses a separate solution for elution that has a different $\mathrm{pH}$, ionic strength, polarity or temperature from the solution used for sample application. The biospecific elution methods in (b) make use of an elution buffer that contains an agent that will compete with the affinity ligand for binding to the target (normal role) or that competes with the target for binding to the affinity ligand (reversed role).

\section{General Principles of Affinity Chromatography}

Figure 1 shows a few ways in which an immobilized affinity ligand can be used in a chromatographic separation. In each of these approaches, a sample that contains the desired target is applied to the column in the presence of a mobile phase that has the correct composition and $\mathrm{pH}$ to promote binding of the target to the affinity ligand. This mobile phase is often referred to as the "application buffer" and represents the weak mobile phase for this column (i.e., the liquid phase in which the column will have its highest retention of the target). When the sample is applied to the affinity column in the presence of this mobile phase, the target will be retained but, due to the selective nature of the immobilized binding agent, other 
components in the sample will tend to pass through the column in the nonretained fraction or as a weakly retained peak. The retained target is then eluted from the column and measured, collected for further use, or passed onto a second method for further separation or analysis.

There are several ways in which the retained target can be removed from the affinity column, as shown in Fig. 1. If this target has only moderately strong binding to the column (e.g., an association equilibrium constant of $10^{5}-10^{6} \mathrm{M}^{-1}$ or less), it may be possible to use isocratic elution. In this approach, known as weak affinity chromatography, the application buffer is utilized both to apply the sample to the affinity column and to later elute the retained target. A more common method is to use a step change or gradient to elute the retained target after the nonretained sample components have left the column. This approach, sometimes known as the "on/off" elution method, uses a second mobile phase to cause the target to leave the column due to dissociation or mass action, as is demonstrated in Fig. 1 through the use of nonspecific elution or biospecific elution. The second mobile phase that is used in this case is called the "elution buffer" and represents the strong mobile phase for the column (i.e., a mobile phase that leads to low target retention). After this elution buffer has removed the target from the column, the original buffer is reapplied and the column is allowed to regenerate prior to the next sample being passed through the column.

As will be shown in this review, there are many types of binding agents, supports, and separation formats that can be employed in affinity chromatography. These features, plus the high selectivity of many affinity ligands, have made this method popular in the largescale purification of enzymes and biopharmaceuticals [2-4]. Other applications have included the small-scale isolation of recombinant proteins, the analysis of specific chemicals in biological or pharmaceutical samples, and the study of biological interactions [2-6]. The remainder of this review will examine the history of affinity chromatography and consider events and trends that have led to the development and current applications of this technique. 


\section{The Origins of Affinity Chromatography}

The first known report of a separation that used affinity chromatography occurred in the early 1900s. This was a period of time in which the method of liquid chromatography itself was still in its infancy. Some work had already been carried out in the late 1800 for liquid-phase separations based on the adsorption of chemicals to planar supports [1]. In addition, the utilization of packed columns and the adsorption of targets to a solid support had been explored in 19031907 by Michael Tswett for the separation of plant pigments [8]. A few years later, in 1910, Emil Starkenstein studied binding by the enzyme $\alpha$-amylase to a column containing insoluble starch [9]. The method used by Starkenstein, which was based on the natural interactions that occur between $\alpha$-amylase and starch, this enzyme's substrate, was not only the first known example of affinity chromatography but was also one of earliest examples of a separation in which liquid chromatography was used with an enzyme or protein.

Methods similar to the one used by Starkenstein were soon described by others who were working with the enzyme amylase. Examples included several papers which appeared over the next few decades, such as work by Ambard in 1921 [10], Holmbergh in 1933 [11], Tokuoka in 1937 [12], and Hockenhull and Herbert in 1945 [13]. In one of these reports, a 300-fold purification of amylase was even reported [14]. This general approach was also adopted for the purification or isolation of other enzymes that had substrates which could be obtained in a solid or powdered form and used as support materials. For instance, in 1934 Northrup used edestin, a crystalline protein, to purify the protease pepsin [14]. Lineweaver et al. employed polygalacturonase in 1949 as both a support and affinity ligand for binding to alginic acid [15]. In addition, Grant and Robbins described work in 1957 in which they used powdered elastin to isolate the enzyme porcine elastase [16].

As these efforts were made on the use of substrates and solid supports to purify enzymes, parallel reports appeared on the purification of antibodies by their selective binding to biological ligands. This type of work with antibodies was based on a report in 1920 by Landsteiner in which it was found that antibodies could bind "antigens" (i.e., chemicals that had a specific and complementary structure to the 
antibodies) [17]. In addition, it was found that large antigens could bind with polyclonal antibodies to form complexes that precipitated from an aqueous solution. The result was the creation of a method known as immunoprecipitation, which appeared in the 1930 s as a tool for antibody characterization and purification [18-20]. As an example, immunoprecipitation was utilized in 1934 by Kirk and Sumner to purify antibodies for urease and to demonstrate that these antibodies were proteins [18]. Although this particular approach was not yet at the point where it would now be called "chromatography," such work did demonstrate that the use of selective binding for purification and analysis was not limited to enzyme-substrate interactions but could be extended to antibody-antigen binding, and perhaps other types of biological systems.

\section{Early Developments in Affinity Supports and Immobilization Methods}

The earliest affinity-based separations, as described in the previous section, all made use of naturally occurring materials as both the support and binding agent. Examples included the use of supports such as insoluble starch for the isolation of amylase [9-13], polygalacturonase for alginic acid [15], crystalline edestin for pepsin [14], and powdered elastin for elastase [16]. The reports that utilized immunoprecipitation employed a similar scheme based on naturally occurring solid supports, but in these studies the support was the precipitate that was created as the result of the specific binding between an antigen and its antibodies [18-20].

The next step in the development of affinity-based separations was the creation of supports which could be used for binding agents and targets for which naturally occurring ligand/support combinations were not available. This work first involved binding agents that were attached to supports by means of noncovalent adsorption. One example of this occurred in 1935 when D'Alessandro and Sofia coated antigens onto charcoal or kaolin and used these modified supports to isolate antibodies that were related to tuberculosis and syphilis [21]. A similar antibody-purification method that used antigens on kaolin was described by Meyer and Pic in 1936 [22]. Although these supports 
were relatively easy to prepare, one issue in using a support prepared by ligand adsorption was that the binding properties of such a material may not have good long-term stability due to gradual loss of the binding agent [2].

Approaches for the creation of supports that contained covalently linked binding agents soon began to appear. This approach was used in 1936 by Landsteiner and van der Scheer, who adapted a diazo coupling method that had already been used to prepare hapten conjugates [23]. In their modified approach, they used this method to couple various haptens to chicken erythrocyte stroma. This modified material was then used to isolate antibodies that could bind to the immobilized haptens. Another important advance took place in 1951 in work by Campbell, Luescher and Lerman [24]. In their research, they activated cellulose to give $p$-aminobenzylcellulose, which was then used to immobilize bovine serum albumin (BSA). The resulting material was employed in the isolation of anti- BSA antibodies that were present in pooled serum from rabbits that had previously been injected and immunized with BSA [24].

Other reports that used binding agents covalently linked to solid supports soon began to appear. For instance, the same method as used by Campbell et al. was employed by Lerman to immobilized haptens in 1953 for "antibody chromatography" [25]. Lerman also used this approach to prepare a support with an immobilized ligand for the purification of mushroom tyrosinase [26]. Other reports using covalently linked antigens for antibody purification appeared in 1955 by Manecke and Gillert, who used polyaminostyrene as the support [27], and in 1958 by Sutherland and Campbell, who utilized glass beads for antigen immobilization [28]. From 1957 through 1966, several reviews and additional papers appeared on methods for the covalent immobilization of antigens, enzymes or antibodies to solid materials [29-35]. Much of this work focused on supports containing immobilized antibodies, antigens or haptens, but some reports related to enzyme purification were published as well. Of particular interest in this latter group were two papers by Arsenis and McCormick in 1964 and 1966, in which various flavin-cellulose supports were used for the purification of flavokinase [36] and flavin mononucleotidedependent enzymes [37]. 


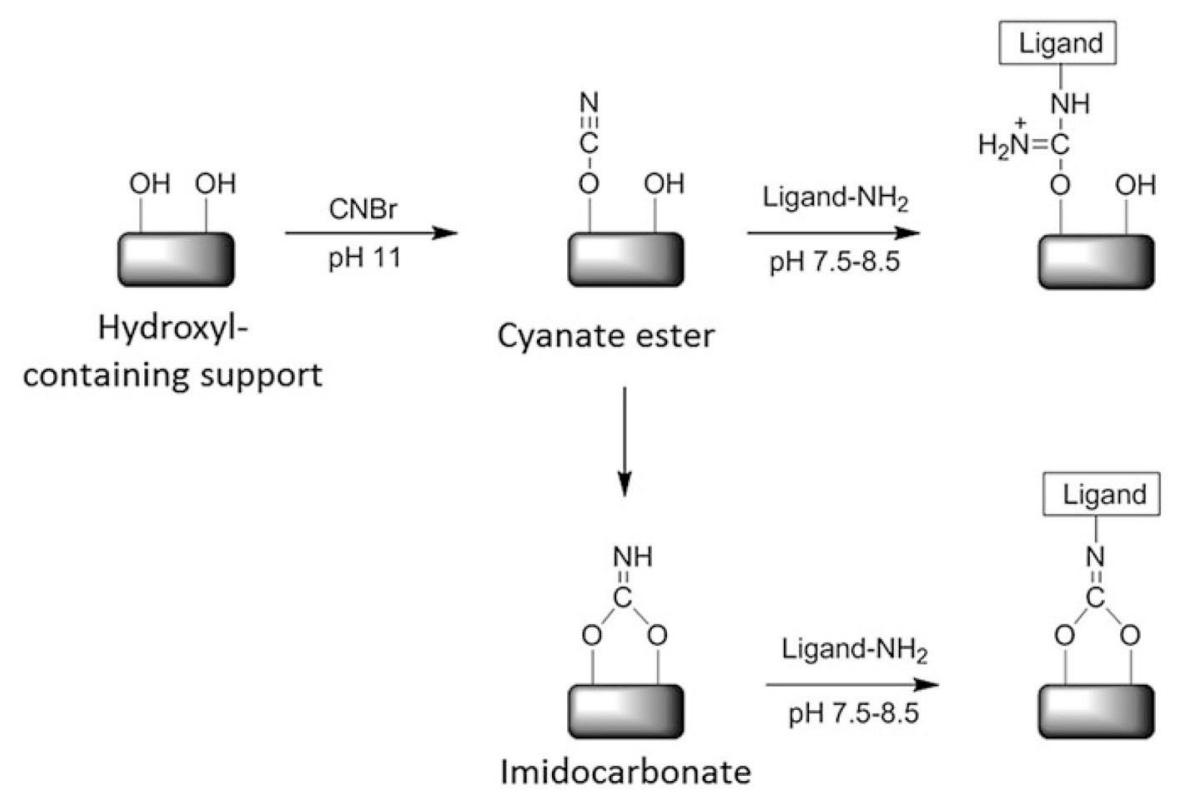

Fig. 2 The cyanogen bromide ( $\mathrm{CNBr}$ ) immobilization method. This figure shows two possible routes by which ligands can be coupled to a support.

There were a series of critical developments that next occurred around the mid- to late-196os. One of these developments was the creation of beaded agarose by Hjerten in 1964 [38]. This material was important because it was more efficient and more readily adaptable than cellulose for use with proteins and biopolymers in liquid chromatography. A second development, which occurred in 1967, was the description of the cyanogen bromide immobilization method by Axen, Porath, and Ernback (see Fig. 2) [39]. The value of this immobilization method was that it allowed for a general and relatively convenient means for covalently coupling peptides and proteins to polysaccharide-based materials. In 1968, Cuatrecasas, Wilchek, and Anfinsen [40] combined these two approaches when they used the cyanogen bromide method to immobilize nuclease inhibitors to beaded agarose. These supports were then placed into columns and used to purify several enzymes, including carboxypeptidase A, $\alpha$-chymotrypsin, and staphylococcal nuclease [40]. This general method was adapted by many others [2-6] and became known by the name "affinity chromatography" $[2-7,40]$. 


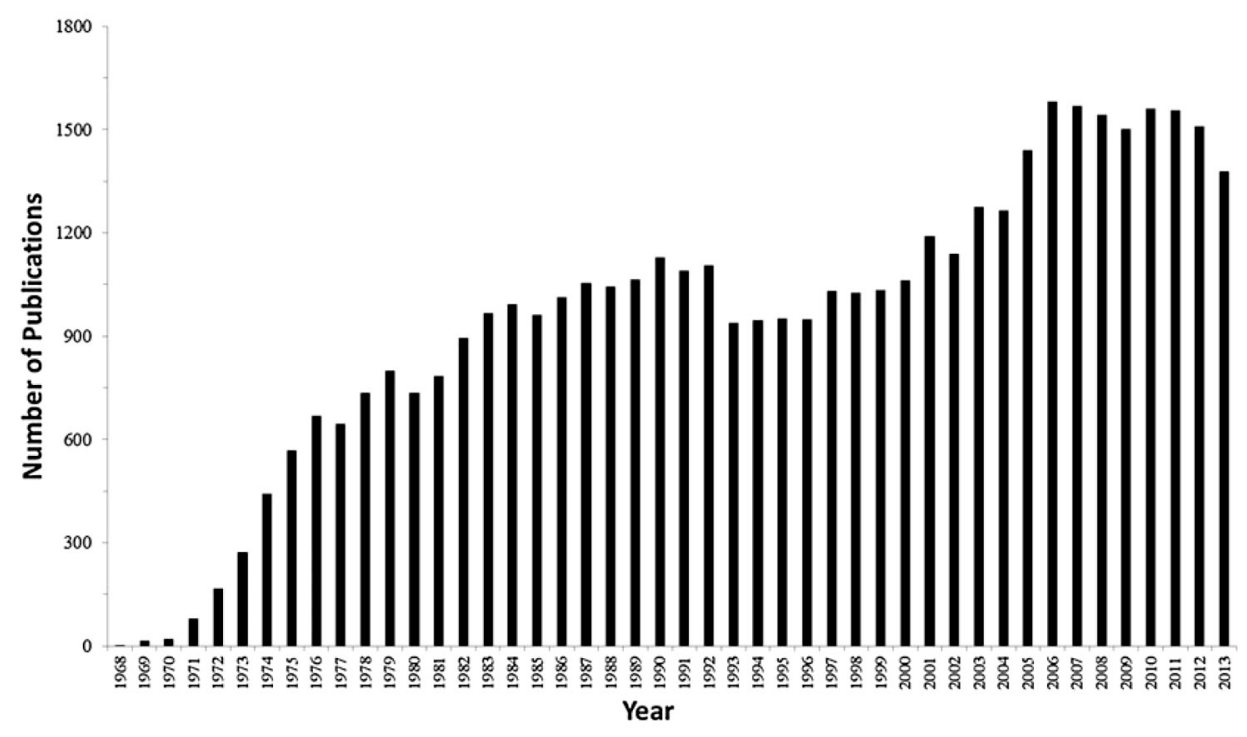

Fig. 3 Number of publications including the term "affinity chromatography" and that appeared between 1968 and 2013. These data were obtained through a search that was conducted in April 2014 on the Web of Science.

\section{The Modern Area of Affinity Chromatography}

Immediately after 1968, there was rapid growth in the field of affinity chromatography and in the applications of this method. This growth is indicated in Fig. 3 by the way in which the number of publications including the term "affinity chromatography" grew from only a few in the late 1960s to around 1,00o papers per year or more by the early 1980 s. Over the last decade, this number has risen to around 1,500 papers per year, giving a total of over 43,000 publications on this topic that have appeared between 1968 and 2013. This period of time has also seen the creation of a large range of methods and applications that make use of affinity chromatography. The remainder of this review will briefly consider many of these developments.

\subsection{Advances in Affinity Ligands}

One way in which affinity chromatographic methods can be categorized is in terms of the type of binding agent that is present in the column. As was noted earlier, the first binding agents used in this method 
were those that were based on the interactions of enzymes with their substrates, inhibitors or cofactors and on the interactions of antibodies with their antigens. These two groups of interactions are still used in many of the modern applications of affinity chromatography. Examples include the use of affinity chromatography for enzyme purification, antibody isolation, and the selective purification or removal of antigen- or antibody-related targets from samples [2-6].

The use of a biological molecule as the binding agent in affinity chromatography, such as an enzyme or antibody, is a method known as bioaffinity chromatography or biospecific adsorption [2-6, 41]. There are many natural binding agents that have been employed in affinity columns, which has resulted in the development of several subcategories for bioaffinity chromatography. The most common subcategory is one which uses a ligand that is an antibody or antibody-related agent (e.g., an antigen or an antibody fragment), giving a technique known as immunoaffinity chromatography (IAC) [42-46].

Another subset of bioaffinity chromatography is lectin affinity chromatography, which uses binding agents that consist of lectins (i.e., nonimmune system proteins that can bind to particular carbohydrate residues) [41, 47-49]. Examples of lectins that are often used in affinity columns are concanavalin A (Con A), which can bind to $\alpha$-D-glucose or $\alpha$-D-mannose residues, and wheat germ agglutinin (WGA), which interacts with D- $N$-acetylglucosamine residues [3-6, 41, 49]. Some other natural ligands that have been employed in bioaffinity chromatography are immunoglobulinbinding proteins like protein A or protein $\mathrm{G}$, which can be used for antibody purification or as secondary binding agents to adsorb antibodies to a support [6, 41, 49-52]. In addition, nucleic acids and polynucleotides can be utilized in bioaffinity chromatography to purify enzymes and proteins that bind to DNA or RNA, as well as to retain nucleic acids that have a complementary sequence to the immobilized binding agent [53-55].

Various nonbiological binding agents have also been employed in affinity chromatography. Some illustrations of this approach appeared during the early creation of synthetic agents and modified supports for the purification of enzymes and antibodies, as described in the previous section. Other examples that began to appear in the 1970s included the techniques of immobilized metal-ion affinity chromatography (IMAC) [56], dye-ligand affinity chromatography [57], and boronate affinity chromatography [58], as illustrated in Fig. 4. 
a

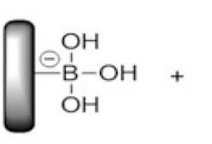

Immobilized boronate anion

b

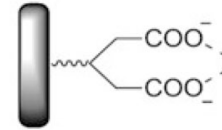

Metal ion chelate

c

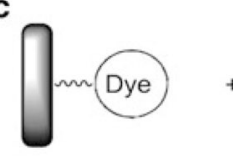

Immobilized dye

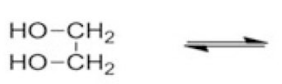

Diol-containing target

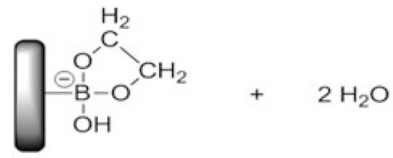

Boronate-target complex

Fig. 4 Examples of nonbiological ligands that are used in (a) boronate affinity chromatography, (b) immobilized metal-ion affinity chromatography (IMAC), and (c) dye-ligand affinity chromatography.

In IMAC, the affinity ligand is a metal ion that is bound to a chelating agent on the support (e.g., $\mathrm{Ni}^{2+}$ on a support that contains iminodiacetic acid, or IDA) $[56,59-62]$. IMAC can retain peptides, proteins and other targets that have electron donor groups, making this method popular in molecular biology for the purification of histidine-tagged proteins and in proteomics for the isolation of phosphorylated proteins [6o]. Dye-ligand affinity chromatography uses a ligand that is a synthetic dye, such as Cibacron Blue 3GA [3, 57]. The good stability, low cost, and ability to custom design these ligands for a given target have made dye-ligand affinity chromatography popular for the large-scale purification of proteins and enzymes $[63,64]$. Boronate affinity chromatography is based on the use of boronic acid or a related derivative as a ligand. This type of ligand can retain targets that contain cis-diol groups, such as catecholamines and many compounds with sugar residues (e.g., polysaccharides, glycoproteins, and ribonucleic acids) [65-67].

The last few decades have seen increasing interest in the generation of new types of affinity ligands through a variety of techniques. One example is a technique known as biomimetic affinity chromatography [63]. As the term "biomimetic" suggests, this method seeks to generate or select a ligand that can mimic the binding of a desired target to some natural compound. This approach includes the use of 
synthetic dyes as ligands, making dye-ligand affinity chromatography a subset of these biomimetic techniques [63]. There are many ways in which artificial ligands can be produced. Some examples of these approaches are the use of phage display libraries, aptamer libraries, and ribosome display libraries. The creation of affinity ligands through the use of peptide libraries, combinatorial chemistry, and computer modeling has also been an area of active research [63, 68, 69].

An alternative approach that has been explored to create artificial ligands is molecular imprinting [70-73]. In this technique, the affinity ligand is a binding pocket for the target and is formed during creation of the support. This material can be prepared by combining a known portion of the desired target with a polymerization mixture that contains a cross-linking agent, an initiating agent for polymerization, and one or more monomers with functional groups that can interact with the target. As this mixture polymerizes and forms the support, pockets are produced about the target that have a shape and set of functional groups that complement the target's structure. After this molecularly imprinted polymer (MIP) has been generated, the target is removed and the pockets in this material are utilized as affinity ligands to retain and bind the same target in samples that are applied to this support [70-73].

\subsection{Advances in Affinity Supports and Immobilization Methods}

Another way affinity chromatography has continued to develop is in the types of supports and immobilization methods that have been employed in this technique. Carbohydrate-based materials such as agarose remain the most common media for preparative applications of affinity chromatography. Features of these supports that make them useful for large-scale purifications and sample pretreatment include their low nonspecific binding, low cost, and ability to be used over a broad $\mathrm{pH}$ range for elution or with solutions that are often employed for column sterilization. These supports can also be employed with a variety of immobilization methods [2-6, 49, 74]. The main downside for many of these materials is their relatively low efficiency and their ability to be used at only modest back pressures. A method with such properties is sometimes known as low-performance (or column) affinity chromatography $[2,75,76]$.

Soon after beaded agarose was used in affinity chromatography, alternative supports were considered for this method. Some of these 
materials were based on silica or glass beads, which provided better efficiencies and mechanical stability than carbohydrate-based supports. The use of such materials gave a method known as high performance affinity chromatography or high-performance liquid affinity chromatography [6, 76-79]; however, these supports did require some prior modification to minimize their nonspecific binding for biological agents [6]. A range of synthetic organic-based supports were also created for affinity chromatography. These latter supports included azalactone beads, hydroxylated polystyrene, polyacrylamide derivatives, polyethersulfone, and polymethacrylate derivatives, as well as hybrid materials like agarose-acrylamide and dextran-acrylamide copolymers. Like agarose, these alternative supports have now been used with many affinity ligands and immobilization methods [3-6, 32, 78, 79].

There are various forms in which the support can be used in affinity chromatography. The most common form is that of a particulate support that is packed within a column. This type of support may consist of agarose or cellulose beads, silica particles, glass beads, or particles of an organic polymer like azalactone or polyacrylamide. Monolithic supports have also been used with affinity ligands over the last decade, giving a method known as "affinity monolith chromatography"; in this approach, a porous bed made of a continuous material is used in the affinity column [75]. Monolith columns have been prepared by using media such as agarose, silica, polymethacrylate or other organic polymers, and cryogels (e.g., see Fig. 5) [75, $76,79,80]$. Other support formats that have been utilized in affinity

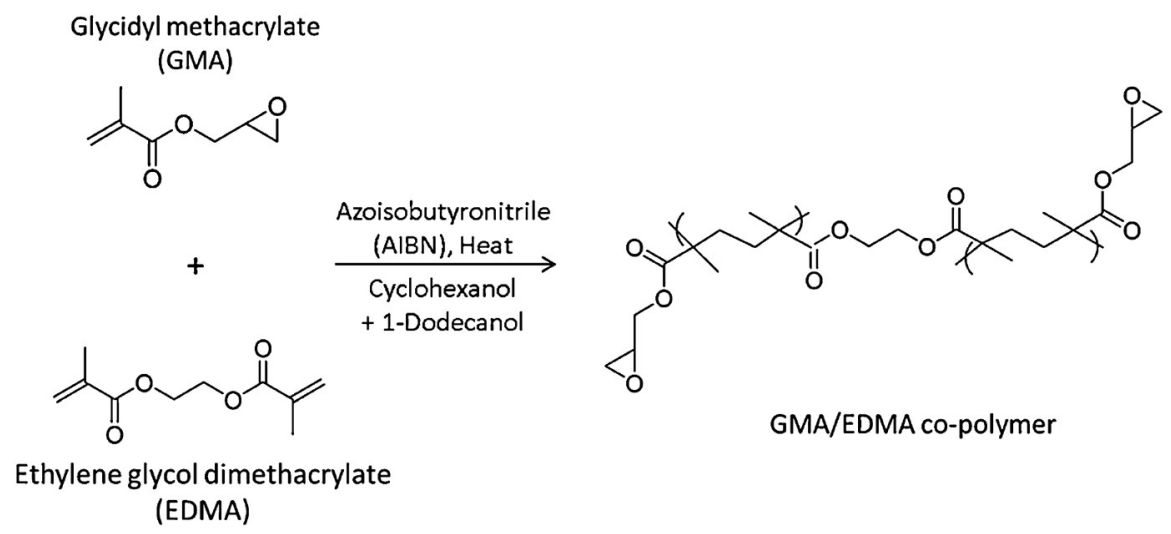

Fig. 5 Typical procedure used to prepare an organic monolith based on a copolymer of glycidyl methacrylate (GMA) and ethylene glycol dimethacrylate (EDMA) for use in affinity monolith chromatography. 
chromatography have included fibers, membranes, nonporous particulate supports, flow-through particles (e.g., perfusion media), and expanded bed particles [79].

The approach that is most frequently used in modern affinity chromatography to place ligands onto these supports is covalent immobilization. There are many methods that can be used for this purpose [3-6, 49, 74, 78]. For example, this might make use of amine groups, carboxylic acids, or sulfhydryl residues in the structure of a ligand such as a protein or peptide. Alternative schemes can also sometimes be employed, such as the use of aldehyde groups that are generated through the oxidation of carbohydrate residues [49, 74, 81]. In addition, many of these procedures can now be carried out by using kits or preactivated supports that are commercially available [49, 74].

Physical adsorption, which was used in some early forms of affinity chromatography, is still used on occasion for ligand immobilization. This method is usually easy to carry out but can result in a ligand that may wash from the column over time or may use a support material that will have nonspecific binding to some sample components [74]. A common variation of this method is biospecific adsorption, which uses a secondary ligand that is coupled within the column to selectively adsorb the final desired affinity ligand. A few examples of this approach are the use of immobilized streptavidin or avidin to bind to affinity ligands that have been tagged with biotin, and the use of immobilized protein A or protein $\mathrm{G}$ to adsorption antibodies to affinity supports $[41,43,49,74]$.

Another method for ligand immobilization that has been of interest is entrapment or encapsulation [74]. One way to accomplish this is to combine the affinity ligand with the chemicals that are used to make an affinity support, such as occurs when a sol-gel is prepared in the presence of a protein or other type of ligand [74]. It is also possible to place large ligands like liposomes or membrane-based particles within the pores of some supports (e.g., agarose) by altering the size of the ligand particles through a process such as freeze-drying $[82,83]$. Another approach that has recently been used for entrapment is to place soluble proteins and other affinity ligands in porous supports by at least partially blocking the support's pores through the use of a large capping agent [84, 85]. 


\subsection{Advances in Applications of Affinity Chromatography and Related Methods}

As was true during the initial development of affinity chromatography, one of the key applications for this method is its use in the selective purification of biochemicals. The variety of ligands and supports that are now available have made this technique valuable for both small- and large-scale purification methods. A small-scale example is the use of IMAC to isolate and purify histidine-tagged proteins, as are often produced in molecular biology [6o]. Important examples of large-scale purifications include the use of various forms of affinity chromatography to isolate enzymes, recombinant proteins, and biopharmaceutical products [63, 64, 86-90].

The high selectivity of affinity ligands, and the creation of improved support materials for these ligands, has also led to the growth of affinity chromatography as an important tool for chemical analysis [2, $6,76-80]$. This has included the use of this method in fields that have ranged from biochemistry and clinical chemistry to pharmaceutical analysis and environmental science [88, 91-94]. Some of these applications have used affinity chromatography as a means of binding to a particular target and then measuring this target directly as it elutes from the affinity column [6, 43, 46, 92-96]. In some cases, such as chiral separations, an affinity column can be used to retain and resolve multiple targets that bind to the affinity ligand [92, 97-100]. Many other examples have used affinity ligands, and especially antibodies, to extract a given target or group of targets prior to the analysis of these compounds by a second method (e.g., reversed phase chromatography, gas chromatography, capillary electrophoresis, or mass spectrometry) [42-44, 96, 101, 102]. Affinity columns have also been employed with various detection schemes for the indirect detection of a target, such as occurs in the use of antibodies in chromatographic-based immunoassays or in schemes that employ post column immunodetection to examine specific targets as they elute from more traditional types of liquid chromatographic columns [44, 46, 95, 96, 102, 103]. Both the specificity and strong binding of many biological ligands have also made affinity columns attractive in recent years as components for the processing or analysis of targets by microscale analytical devices [96, 101, 104, 105]. 
Another application for affinity chromatography has been the use of this method in the study of biological interactions [106-111]. Zonal elution is one approach that was used as early as 1973-1974 for this purpose $[112,113]$ and has been employed with such systems as protein-protein, drug-protein, and enzyme- inhibitor interactions [106, 107, 109]. This method makes use of the injection of a small amount of a probe compound or solute onto an affinity column, and is usually done in the presence of a competing agent or additive in the mobile phase. This method can provide data on the binding strength of the ligand to the injected probe/solute or additive and on the types of interactions that are present between these agents [107, 109]. Frontal analysis, or frontal affinity chromatography (FAC), is an alternative approach for binding studies that has been used since 1975 [114]. This method involves the continuous application of a known concentration of a target to an affinity column, with the results being used to find the equilibrium constant(s) and number of binding sites for the target with the affinity ligand [106, 107, 109]. In the early-to-mid 1990s, similar zonal elution and frontal analysis schemes were adapted for use in capillary electrophoresis, creating a set of methods now known as affinity capillary electrophoresis (ACE) [115-119].

Work in the mid-1970s through early-1980s also lead to the development of various ways for examining the kinetics of biological interactions by using affinity chromatography. An early example of such an approach was a variation on zonal elution that made use of bandbroadening measurements [106, 120-122]. Other methods that were described for kinetic studies included those based on the split-peak effect, peak decay analysis, and various peak fitting methods [106, 107, 109, 123-130]. Similar work was then conducted in the use of immobilized affinity ligands and flow through biosensors for kinetic studies $[108,131]$. One result of these efforts was the creation of sensors and devices that could determine the degree or rate of a target-ligand interaction at a surface by measuring changes in optical properties, such as based on surface plasmon resonance (SPR) [131-133].

\section{Conclusion}

Over the last one hundred years, affinity chromatography has grown from a method that could be used to isolate only a few enzymes 
or antibodies to a powerful technique that has a broad range of applications in chemical separations and analysis. This growth has been made possible by the availability of many binding agents, support materials, and immobilization methods that can now be used with this technique. These developments, in turn, have made it possible for affinity chromatography to become an important separation method for both the large- and small-scale purification of biochemicals. Other applications that have appeared for this method have included its use in the direct or indirect detection of targets and its combination with other methods of chemical analysis. Affinity chromatography has also become a valuable tool for the study of biological interactions and has led to the creation of related affinity methods, such as the use of flowbased sensors to examine biological interactions and affinity capillary electrophoresis. As a result of the many current applications for this method, it is expected that affinity chromatography will continue to grow and develop in the future as a vital tool in areas that span from the production of biopharmaceuticals to clinical analysis, environmental testing, pharmaceutical testing, and biomedical research.

Acknowledgments - This work was supported, in part, by the National Institutes of Health under grants Ro1 DKo69629 and Ro1 GMo44931 and by the National Science Foundation under grants CMI 1309806 and EPS 1004094.

\section{References}

1. Poole CF, Poole SK (1991) Chromatography today. Elsevier, Amsterdam

2. Hage DS (ed) (2006) Handbook of affinity chromatography, 2nd edn. Boca Raton, Taylor \& Francis

3. Turkova J (1978) Affinity chromatography. Elsevier, Amsterdam

4. Scouten WH (1981) Affinity chromatography: bioselective adsorption on inert matrices. Wiley, New York

5. Parikh I, Cuatrecasas P (1985) Affinity chromatography. Chem Eng News 63:17-32

6. Walters RR (1985) Affinity chromatography. Anal Chem 57:1099A-1114A

7. Ettre LS (1993) Nomenclature for chromatography. Pure Appl Chem 65:819-872

8. Tswett M (1907) The chemistry of chlorophyll, phylloxanthin, phyllocyanin, and chlorophyllane. Biochem Z 5:6-32

9. Starkenstein E (1910) Ferment action and the influence upon it of neutral salts. Biochem Z 24:210-218 
10. Ambard L (1921) Amylase: its estimation and the mechanism of its action. Bull Soc Chim Biol 3:51-65

11. Holmbergh O (1933) Adsorption of $\alpha$-amylase from malt by starch. Biochem $Z$ 258:134-140

12. Tokuoka Y (1937) Koji amylase IX: existence of $\beta$-amylase. J Agric Chem Soc Japan 13:586-594

13. Hockenhull DJD, Herbert D (1945) The amylase and maltase of Clostridium acetobutylcium. Biochem J 39:102-106

14. Northrup JH (1934) Crystalline pepsin, VI: inactivation by $\beta$ - and $\gamma$-rays from radium and by ultraviolet light. J Gen Physiol 17:359-363

15. Lineweaver H, Jang R, Jansen EF (1949) Specificity and purification of polygalacturonase. Arch Biochem 20:137-152

16. Grant NH, Robbins KC (1957) Porcine elastase and proelastase. Arch Biochem Biophys 66:396-403

17. Landsteiner K (1920) Specific serum reactions induced by the addition of substances of known constitution (organic acids), XVI: antigens and serological specificity. Biochem Z 104:280-299

18. Kirk JS, Sumner JB (1934) The reaction between crystalline urease and antiurease. J Immunol 26:495-504

19. Marrack JR, Smith FC (1932) Quantitative aspects of immunity reactions: the combination of antibodies with simple haptenes. Br J Exp Pathol 13:394-402

20. Heidelberger M, Kabat EA (1938) Quantitative studies on antibody purification, II: the dissociation of antibody from pneumococcusspecific precipitates and specifically agglutinated pneumococci. J Exp Med 67:181-199

21. D'Alessandro G, Sofia F (1935) The adsorption of antibodies from the sera of syphilitics and tuberculosis patients. Z lmmunitats 84:237-250

22. Meyer K, Pic A (1936) Isolation of antibodies by fixation on an adsorbentantigen system with subsequent regeneration. Ann Inst Pasteur 56:401-412

23. Landsteiner K, van der Scheer J (1936) Cross reactions of immune sera to azoproteins. J Exp Med 63:325-339

24. Campbell DH, Luescher E, Lerman LS (1951) Immunologic adsorbents I: isolation of antibody by means of a cellulose-protein antigen. Proc Natl Acad Sci U S A 37:575-578

25. Lerman LS (1953) Antibody chromatography on an immunologically specific adsorbent. Nature 172:635-636

26. Lerman LS (1953) A biochemically specific method for enzyme isolation. Proc Natl Acad Sci U S A 39:232-236

27. Manecke G, Gillert KE (1955) Serologically specific adsorbents.

Naturwissenschaften 42:212-213

28. Sutherland GB, Campbell DH (1958) The use of antigen-coated glass as a specific adsorbent for antibody. J Immunol 80:294-298

29. Isliker HC (1957) Chemical nature of antibodies. Adv Prot Chem 12:387-463

30. Kabat EA, Mayer MM (1961) Experimental immunochemistry, 2nd edn. Thomas, Springfield, pp 781-797 
31. Manecke G (1962) Reactive polymers and their use for the preparation of antibody and enzyme resins. Pure Appl Chem 4:507-520

32. Sehon AH (1963) Physicochemical and immunochemical methods for the isolation and characterization of antibodies. Br Med Bull 19:183-191

33. Weliky N, Weetall HH, Gilden RV, Campbell DH (1964) Synthesis and use of some insoluble immunologically specific adsorbents. Immunochemistry 1:219-229

34. Weliky N, Weetall HH (1965) Chemistry and use of cellulose derivatives for the study of biological systems. Immunochemistry 2:293-322

35. Silman IH, Katchalski E (1966) Waterinsoluble derivatives of enzymes, antigens, and antibodies. Annu Rev Biochem 35:873-908

36. Arsenis C, McCormick DB (1964) Purification of liver flavokinase by column chromatography on flavine-cellulose compounds. J Biol Chem 239:3093-3097

37. Arsenis C, McCormick DB (1966) Purification of flavin mononucleotidedependent enzymes by column chromatography on flavin phosphate cellulose compounds. J Biol Chem 241:330-334

38. Hjerten S (1964) The preparation of agarose spheres for chromatography of molecules and particles. Biochem Biophys Acta 79:393-398

39. Axen R, Porath J, Ernback S (1967) Chemical coupling of peptides and proteins to polysaccharides by means of cyanogen halides. Nature 214:1302-1304

40. Cuatrecasas P, Wilchek M, Anfinsen CB (1968) Selective enzyme purification by affinity chromatography. Proc Natl Acad Sci U S A 68:636-643

41. Hage DS, Bian M, Burks R, Ohnmacht C,Wa C (2005) Bioaffinity chromatography. In: Hage DS (ed) Handbook of Affinity Chromatography, 2nd edn. Taylor and Francis, Boca Raton, Chapter 5

42. Calton GJ (1984) Immunosorbent separations. Methods Enzymol 104:381-387

43. Hage DS, Phillips TM (2006) Immunoaffinity chromatography. In: Hage DS (ed) Handbook of Affinity Chromatography, 2nd edn. Taylor and Francis, Boca Raton, Chapter 6

44. Moser AC, Hage DS (2010) Immunoaffinity chromatography: an introduction to applications and recent developments. Bioanalysis 2:769-790

45. Fitzgerald J, Leonard P, Darcy E, O’Kennedy R (2011) Immunoaffinity chromatography. Methods Mol Biol 681:35-59

46. Hage DS (1998) A survey of recent advances in analytical applications of immunoaffinity chromatography. J Chromatogr B Biomed Sci Appl 715:3-28

47. Liener IE, Sharon N, Goldstein IJ (1986) The lectins: properties, functions and applications in biology and medicine. Academic, London

48. West I, Goldring O (1996) Lectin affinity chromatography. Methods Mol Biol 59:177-185

49. Hermanson GT, Mallia AK, Smith PK (1992) Immobilized affinity ligand techniques. Academic, New York

50. Lindmark R, Biriell C, Sjoquist J (1981) Quantitation of specific IgG antibodies in rabbits by a solid-phase radioimmunoassay with 125I-protein A from Staphylococcus aureus. Scand J Immunol 14:409-420 
51. Ey PL, Prowse SJ, Jenkin CR (1978) Isolation of pure IgG1, IgG2a and IgG2b immunoglobulins from mouse serum using protein Asepharose. Immunochemistry 15:429-436

52. Bjorck L, Kronvall G (1984) Purification and some properties of streptococcal protein G, a novel IgG-binding reagent. J Immunol 133:969-974

53. Alberts BM, Amodio FJ, Jenkins M, Gutmann ED, Ferris FL (1968) Studies with DNA-cellulose chromatography I: DNAbinding proteins from Escherichia coli. Cold Spring Harb Symp Quant Biol 33:289-305

54. Weissbach A, PoonianM(1974) Nucleic acids attached to solid matrices. Methods Enzymol 34:463-475

55. Moxley RA, Oak S, Gadgil H, Jarrett HW (2006) DNA affinity chromatography. In: Hage DS (ed) Handbook of affinity chromatography, 2nd edn. Taylor and Francis, Boca Raton, Chapter 7

56. Porath J, Carlsson J, Olsson I, Belfrage B (1975) Metal chelate affinity chromatography, a new approach to protein fractionation. Nature 258:598-599

57. Staal G, Koster J, Kamp H, Van Milligen- Boersma L, Veeger C (1971) Human erythrocyte pyruvate kinase, its purification and some properties. Biochem Biophys Acta 227:86-92

58. Weith HL, Wiebers JL, Gilham PT (1970) Synthesis of cellulose derivatives containing the dihydroxyboryl group and a study of their capacity to form specific complexes with sugars and nucleic acid components. Biochemistry 9:4396-4401

59. Chaga GS (2001) Twenty-five years of immobilized metal ion affinity chromatography: past, present and future. J Biochem Biophys Methods 49:313-334

6o. Todorova D, Vijayalakshmi MA (2006) Immobilized metal-ion affinity chromatography. In: Hage DS (ed) Handbook of Affinity Chromatography, 2nd edn. Taylor and Francis, Boca Raton, Chapter 10

61. Cheung RCF, Wong JH, Ng TB (2012) Immobilized metal ion affinity chromatography: a review on its applications. Appl Microbiol Biotechnol 96:1411-1420

62. Kaagedal L (2011) Immobilized metal ion affinity chromatography. Methods Biochem Anal 54:183-201

63. Labrou NE, Mazitsos K, Clonis YD (2006) Dye-ligand and biomimetic affinity chromatography. In: Hage DS (ed) Handbook of Affinity Chromatography, 2nd edn. Taylor and Francis, Boca Raton, Chapter 9

64. Janson J-C (ed) (2011) Protein purification: principles, high resolution methods, and applications. Wiley, Hoboken

65. Bergold A, Scouten WH (1983) Solid phase biochemistry. In: Scouten WH (ed) Borate chromatography. Wiley, New York, pp 149-187

66. Liu XC, Scouten WH (2006) Boronate affinity chromatography. In: Hage DS (ed) Handbook of affinity chromatography, 2nd edn. Taylor and Francis, Boca Raton, Chapter 8 
67. Liu XC, Scouten WH (2000) Boronate affinity chromatography. In: Bailon P, Ehrlich GK, Fung WJ, Berthold W (eds) Affinity chromatography. Humana Press, Totowa, Chapter 12

68. Roming TS, Bell C, Drolet DW (1999) Aptamer affinity chromatography: combinatorial chemistry applied to protein purification. J Chromatogr B Biomed Sci Appl 731:275-284

69. Huang PY, Carbonell RG (2000) Affinity chromatographic screening of soluble combinatorial peptide libraries. Biotechnol Bioeng 63:633-641

70. Kriz D, Ramstrom O, Mosbach K (1997) Molecular imprinting-new possibilities for sensor technology. Anal Chem 69:345A-349A

71. Sellergren B (2001) Molecularly imprinted polymers-man-made mimics of antibodies and their applications in analytical chemistry. Elsevier, Amsterdam

72. Komiyama M, Takeuchi T, Mukawa T, Asanuma H (2002) Molecular imprinting-from fundamentals to applications. Wiley-VCH, Weinheim

73. Haupt K (2006) Molecularly imprinted polymers-artificial receptors for affinity separations. In: Hage DS (ed) Handbook of affinity chromatography, 2nd edn. Taylor and Francis, Boca Raton, Chapter 30

74. Kim HS, Hage DS (2006) Immobilization methods for affinity chromatography. In: Hage DS (ed) Handbook of affinity chromatography, 2nd edn. Taylor and Francis, Boca Raton, Chapter 3

75. Mallik R, Hage DS (2006) Affinity monolith chromatography. J Sep Sci 12:1686-1704

76. Pfaunmiller EL, Paulemond ML, Dupper CM, Hage DS (2013) Affinity monolith chromatography: a review of principles and recent analytical applications. Anal Bioanal Chem 405:2133-2145

77. Ohlson S, Hansson L, Larsson PO, Mosbach K (1978) High performance liquid affinity chromatography (HPLAC) and its application to the separation of enzymes and antigens. FEBS Lett 93:5-9

78. Larsson PO (1984) High-performance liquid affinity chromatography. Methods Enzymol 104:212-223

79. Gustavsson PE, Larsson PO (2006) Support materials for affinity chromatography. In: Hage DS (ed) Handbook of affinity chromatography, 2nd edn. Taylor and Francis, Boca Raton, Chapter 2

80. Yoo MJ, Hage DS (2010) Affinity monolith chromatography: principles and recent developments. In: Wang P (ed) Monolithic chromatography and its modern applications. ILM Publications, UK, Chapter 1

81. Hage DS (2000) Periodate oxidation of antibodies for site-selective immobilization in immunoaffinity chromatography. In: Bailon P, Ehrlich GW, Fung W-J, Berthold W (eds) Affinity chromatography: methods and protocols. Humana Press, Totowa, Chapter 7

82. Zeng CM, Zhang Y, Lu L, Brekkan E, Lundqvist A, Lundahl P (1997) Immobilization of human red cells in gel particles for chromatographic activity studies of the glucose transporter Glut1. Biochim Biophys Acta 1325:91-98 
83. Yang Q, Lundahl P (1995) Immobilized proteoliposome affinity chromatography for quantitative analysis of specific interactions between solutes and membrane proteins: interaction of cytochalasin B with the glucose transporter Glut 1. Biochemistry 34:7289-7294

84. Jackson AJ, Xuan H, Hage DS (2010) Entrapment of proteins in glycogencapped and hydrazide-activated supports. Anal Biochem 404:106-108

85. Jackson AJ, Anguizola J, Pfaunmiller EL, Hage DS (2013) Use of entrapment and high-performance affinity chromatography to compare the binding of drugs and sitespecific probes with normal and glycated human serum albumin. Anal Bioanal Chem 405:5833-5841

86. ZachariouM(ed) (2010) Affinity chromatography: methods and protocols. Humana Press, Totowa

87. Subramanian A (2006) General considerations in preparative affinity chromatography. In: Hage DS (ed) Handbook of affinity chromatography, 2nd edn. Taylor and Francis, Boca Raton, Chapter 11

88. Jordan N, Krull IS (2006) Affinity chromatography in biotechnology. In: Hage DS (ed) Handbook of affinity chromatography, 2nd edn. Taylor and Francis, Boca Raton, Chapter 18

89. Wilchek M, Miron T, Kohn J (1984) Affinity chromatography. Methods Enzymol 104:3-55

90. Friedberg F, Rhoads AR (2006) Affinity chromatography of enzymes. In: Hage DS (ed) Handbook of affinity chromatography, 2nd edn. Taylor and Francis, Boca Raton, Chapter 12

91. McConnell JP, Anderson DJ (1993) Determination of fibrinogen in plasma by highperformance immunoaffinity chromatography. J Chromatogr 615:67-75

92. Wolfe CAC, ClarkeW, Hage DS (2006) Affinity methods in clinical and pharmaceutical analysis. In: Hage DS (ed) Handbook of affinity chromatography, 2nd edn. Taylor and Francis, Boca Raton, Chapter 17

93. Nelson MA, Hage DS (2006) Environmental analysis by affinity chromatography. In: Hage DS (ed) Handbook of affinity chromatography, 2nd edn. Taylor and Francis, Boca Raton, Chapter 19

94. Hage DS (1999) Affinity chromatography: a review of clinical applications. Clin Chem 45:593-615

95. Hage DS, Nelson MA (2001) Chromatographic immunoassays. Anal Chem 73:198A-205A

96. Moser AC, HageDS (2006) Chromatographic immunoassays. In: HageDS (ed) Handbook of affinity chromatography, 2nd edn. Taylor and Francis, Boca Raton, Chapter 29

97. Allenmark S (1991) Chromatographic enantioseparation: methods and applications, 2nd edn. Ellis Horwood, New York

98. Patel S, Wainer IW, Lough WJ (2006) Affinity-based chiral stationary phases. In: Hage DS (ed) Handbook of affinity chromatography, 2nd edn. Taylor and Francis, Boca Raton, Chapter 21 
99. Wainer IW (ed) (1993) Drug stereochemistry: analytical methods and pharmacology, 2nd edn. New York, Marcel Dekker

100. Haginaka J (2001) Protein-based chiral stationary phases for highperformance liquid chromatographic enantioseparations. J Chromatogr A 906:253-273

101. Briscoe CJ, ClarkeW, HageDS (2006) Affinity mass spectrometry. In: Hage DS (ed) Handbook of affinity chromatography, 2nd edn. Taylor and Francis, Boca Raton, Chapter 27

102. de Frutos M, Regnier FE (1993) Tandem chromatographic-immunological analysis. Anal Chem 65:17A-25A

103. Irth H, Oosterkamp AJ, Tjaden UR, van der Greef J (1995) Strategies for online coupling of immunoassays to HPLC. Trends Anal Chem 14:355-361

104. Phillips TM, Hage DS (2006) Microanalytical methods based on affinity chromatography. In: Hage DS (ed) Handbook of affinity chromatography, 2nd edn. Taylor and Francis, Boca Raton, Chapter 28

105. Phillips TM, KalishH(2013) Clinical applications of capillary electrophoresis. Human Press, New York

106. Chaiken IM (ed) (1987) Analytical affinity chromatography. CRC Press, Boca Raton

107. Hage DS, Chen J (2006) Quantitative affinity chromatography - practical aspects. In: Hage DS (ed) Handbook of affinity chromatography, 2nd edn. Taylor and Francis, Boca Raton, Chapter 22

108. Winzor DJ (2006) Quantitative affinity chromatography - recent theoretical developments. In: Hage DS (ed) Handbook of affinity chromatography, 2nd edn. Taylor and Francis, Boca Raton, Chapter 23

109. Schiel JE, Joseph KS, Hage DS (2009) Biointeraction affinity chromatography: general principles and recent developments. In: Grinsberg N, Grushka E (eds) Advances in chromatography, vol 147. Taylor \& Francis, New York, Chapter 4

110. Hage DS, Anguizola JA, Jackson AJ, Matsuda R, Papastavros E, Pfaunmiller E, Tong Z, Vargas-Badilla J, Yoo MJ, Zheng X (2011) Chromatographic analysis of drug interactions in the serum proteome. Anal Methods 3:1449-146o

111. Patel S, Wainer IW, Lough WJ (2006) Chromatographic studies of molecular recognition and solute binding to enzymes and plasma proteins. In: Hage DS (ed) Handbook of affinity chromatography, 2nd edn. Taylor and Francis, Boca Raton, Chapter 24

112. Andrews P, Kitchen BJ, WinzorD (1973) Use of affinity chromatography for the quantitative study of acceptor-ligand interactions: the lactose synthetase system. Biochem J 135:897-900

113. Dunn BM, Chaiken IM (1975) Quantitative affinity chromatography. determination of binding constants by elution with competitive inhibitors. Proc Natl Acad Sci U S A 71:2382-2385

114. Kasai KI, Ishii SI (1975) Quantitative analysis of affinity chromatography of trypsin. A new technique for investigation of protein-ligand interaction. J Biochem 77:261-264 
115. Heegaard NHH, Schou C (2006) Affinity ligands in capillary electrophoresis. In: Hage DS (ed) Handbook of affinity chromatography, 2nd edn. Taylor and Francis, Boca Raton, Chapter 26

116. Kraak JC, Busch S, Poppe H (1992) Study of protein-drug binding using capillary zone electrophoresis. J Chromatogr 6o8:257-264

117. Yang J, Hage DS (1994) Chiral separations in capillary electrophoresis using human serum albumin as a buffer additive. Anal Chem 66:2719-2725

118. Chu Y-H, Whitesides GM (1992) Affinity capillary electrophoresis can simultaneously measure binding constants of multiple peptides to vancomycin. J Org Chem 57:3524-3525

119. Carpenter JL, Camilleri P, Dhanak D, Goodall D(1992)Astudy of the binding of vancomycin to dipeptides using capillary electrophoresis. J Chem Soc Chem Commun 11:804-806

120. Denizot FC, Delaage MA (1975) Statistical theory of chromatography: new outlooks for affinity chromatography. Proc Natl Acad Sci U S A 72:4840-4843

121. Anderson DJ, Walters RR (1986) Equilibrium and rate constants of immobilized concanavalin A determined by high-performance affinity chromatography. J Chromatogr 376:69-85

122. Loun B, Hage DS (1996) Chiral separation mechanisms in protein-based HPLC columns. 1. Kinetic studies of (R)- and (S)- warfarin binding to immobilized human serum albumin. Anal Chem 68:1218-1225

123. Hage DS, Walters RR, Hethcote HW (1986) Split-peak affinity chromatography studies of the immobilization-dependent adsorption kinetics of protein A. Anal Chem 58:274-279

124. Hage DS, Walters RR (1988) Dual-column determination of albumin and mmunoglobulin in serum by high-performance affinity chromatography. J Chromatogr 436:111-135

125. Rollag JG, Hage DS (1998) Non-linear elution effects in split-peak chromatography, II: role of ligand heterogeneity in solute binding to columns with adsorption-limited kinetics. J Chromatogr A 795:185-198

126. Moore RM, Walters RR (1987) Peak-decay method for the measurement of dissociation rate constants by high-performance affinity chromatography. J Chromatogr 384:91-103

127. Chen J, Schiel JE, Hage DS (2009) Noncompetitive peak decay analysis of drugprotein dissociation by high-performance affinity chromatography and peak profiling. J Sep Sci 32:1632-1641

128. Yoo MJ, Hage DS (2011) Use of peak decay analysis and affinity microcolumns containing silica monoliths for rapid determination of drug-protein dissociation rates. J Chromatogr A 1218:2072-2078

129. Jozwiak K, Haginaka J, Moaddel R, Wainer IW (2002) Displacement and nonlinear chromatographic techniques in the investigation of interaction of noncompetitive inhibitors with an immobilized $\alpha_{3} \beta_{4}$ nicotinic acetylcholine receptor liquid chromatographic stationary phase. Anal Chem 74:4618-4624 
130. Moaddel R, Wainer I (2007) Conformational mobility of immobilized proteins. J Pharm Biomed Anal 43:399-406

131. Homola J, Yee SS, Myszka DG (2002) Surface plasmon resonance biosensors. In: Ligler CA (ed) Optical biosensors: present and future. Elsevier, Amsterdam, pp 207-251

132. Rich RL, Myszka DG (2000) Advances in surface plasmon resonance biosensor analysis. Curr Opin Biotechnol 11:54-61

133. Long SD, Myszka DG (2006) Affinity-based optical biosensors. In: Hage DS (ed) Handbook of affinity chromatography, 2nd edn. Taylor and Francis, Boca Raton, Chapter 25 